\title{
The role of executional strategic cost management techniques in supporting firms' triple bottom line performance ${ }^{1}$
}

\author{
دور أدوات الإدارة الإستراتيجية التنفيذية للتكلفة في دعم الأداء \\ الثلاثي للشركات
}

\section{Prepared by: Reham Mohamed Safwat Mohamed} Under supervision of: Prof. Mohamed Mustafa El-Gebally

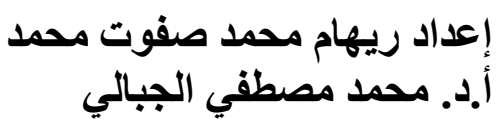

${ }^{1}$ The research is submitted as part of $\mathrm{PhD}$ thesis in Accounting titled; "A proposed framework for supporting firm's triple bottom line performance in Supply Chain context through the structural and executional techniques of strategic cost management: an applied study"

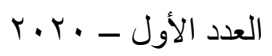$$
07
$$$$
\text { مجلة المحاسبة و المر اجعة لإتحاد الجامعات العربية }
$$ 
The role of executional strategic cost management techniques

لقد أدت المسؤولية الإجتماعية والبيئية للشركات إلي تغير أهدافها لتكون قادرة على تلبية الإحتياجات المختلفة لأصحاب المصالح مما أدي إلي ظهور مصطلح الأداء الثلاتي للشركات والذي ينبغي أن ينعكس علي نظم الإدارة الاستراتيجية للتكلفة، في حين أن القليل من الدراسات السابقة تتاولت التطور في الأداوات التتفيذية للإدارة الاستراتيجية للتكلفة لدعم الأداء الثلاثي للشركات، وبناءً على ذلك يهذف هذا البحث إلى دراسة التطور في الإدارة الإستراتيجية التنفيذية للتكلفة كنظام فرعي لنظام الإدارة الإستراتيجية للتكلفة لدعم الأداء الثلاثي للثركات، وتتاول البحث التطور في ودور كل من التكلفة والإدارة علي أساس النشاط(ABC\& ABM) ، محاسبة تكلفة دورة حياة المنتج (LLC) ومحاسبة تكلفة دورة حياة المنتج المستدام (LCSA)، وبطاقة اللأداء المتوازن المستدام في دعم الأداء الثلاثي للشركات. (SBSC)

الكلمات المفتاحية: الأداء الثلاثي، الإدارة الاستراتيجية التنفيذية للتكلفة، التكلفة والإدارة علي أساس النشاط، محاسبة تكلفة دورة حياة المنتج المستدام، وبطاقة اللأداء المتوازن المستدام. 
The role of executional strategic cost management techniques

ريهام صفوت in supporting firms' triple bottom line performance

\section{$\underline{\text { Abstract }}$}

Firms' social and environmental responsibilities have affected their objectives to be able to satisfy the needs of different stakeholders that led to the emergence of the concept of firms' (Triple Bottom Line) TBL performance which should be reflected in their strategic cost management systems. Little of previous studies have analyzed the development in strategic cost management techniques as result of firms' TBL performance, accordingly this research aims to study the development in executional strategic cost management as a subsystem of strategic cost management system in supporting firms' TBL performance and the research studied the development in and the role of Activity based costing and management (ABC\&ABM), Life cycle costing and Life cycle sustainability assessment (LCSA), and Sustainability balanced scorecard (SBSC) in supporting firms' TBL performance.

Key words: TBL performance, Executional strategic cost management, ABC\&ABM, LCSA, and SBSC. 
The role of executional strategic cost management techniques

ريهام صفوت

in supporting firms' triple bottom line performance

\section{$\underline{\text { Research introduction : }}$}

Changes in social norms during the 1960s 1970s brought different pressures on firms and other organizations, which include demands for greater social and environmental accountability that led to a broader conceptualization on the nature of accounting in the 1980s. That the emergence of different types of environmental and social accounting and reporting can be seen as a practice driven by stakeholders demands and pressures which firms use to explain their social and environmental impacts (Villiers, C., Maroun W., 2017 p.3).

According to firms' social and environmental responsibility, the concept of performance has evolved from the concept of financial performance to a more inclusive concept which includes financial, social, and environmental performance objectives that is the concept of comprehensive performance, so that firm's responsibility is no longer confined to shareholders only, but extended to include other parties called stakeholders.

TBL objectives lead the appearance of social and environmental accounting and reporting practices, and many accounting interventions, such as (Contrafatto, M., Burns, J., 2013, p.351);

(1) Social accounting book-keeping systems

(2) Sustainability reporting

(3) Environmental management systems

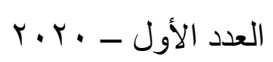$$
09
$$$$
\text { مجلة المحاسبة و المر اجعة لإتحاد الجامعات العربية }
$$ 
The role of executional strategic cost management techniques

ريهام صفوت in supporting firms' triple bottom line performance

(4) Specific social accounting models such as 'sustainability assessment models' (SAM) and 'full cost accounting' (FCA).

Which consequently affected strategic cost management techniques and led to the emergence of many new concepts including; Activity based environmental and social costs, Life cycle sustainability assessment (LCSA), and Sustainable balanced scorecard (SBSC).

\section{$\underline{\text { Research problem }}$}

Firms' social and environmental responsibilities have forced them to integrate environmental and social performance objectives along with their financial progress objectives accordingly strategic cost management as an interactive system must be developed to be able to support firms' TBL performance.

Also previous strategic cost management literature did not study specifically the role of executional strategic cost management as a subsystem of strategic cost management system in supporting firms' TBL performance which creates a research gap needed to be studied.

\section{Research objectives}

The research aims to study;

1- The concept of TBL performance

2- The appropriate measurement of TBL performance

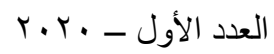$$
7 .
$$$$
\text { مجلة المحاسبة و المر اجعة لإتحاد الجامعات العربية }
$$ 
The role of executional strategic cost management techniques

3- Executional strategic cost management as a subsystem of strategic cost management system

4- The development in executional strategic cost management techniques to support firms' TBL performance.

\section{$\underline{\text { Research plan }}$}

According to research problem and objectives the research will be continued as follows;

1. TBL performance in modern business environment

2. Multidimensional measurement of TBL performance

3. Executional strategic cost management

4. The role of executional strategic cost management in supporting firms' TBL performance

5. Research conclusions

6. References

\section{1-TBL performance in modern business environment}

The concept of TBL was first introduced by Elkington in 1990's (Schulz \& Flanigan, 2016, p.451, Henao, Sarache, and Gómez, 2019, p.100), Elkington, John 1997 argued that firms' future market competitiveness and success depends on their ability to satisfy three prongs which are profitability, environmental quality, and social justice (Svensson, G., et al., 2018).

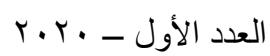


The role of executional strategic cost management techniques

in supporting firms' triple bottom line performance

The TBL represents the three dimensions or components of sustainability: social, environmental and financial sustainability or the three p's "people, planet, profit", the TBL concept has been subsequently adopted by firms to achieve their sustainability objectives.

Profit refers to performance that leads to financial sustainability, Planet related to performance that ensure environmental friendly choices and operations that ensure environmental sustainability, and People is about performance that guaranty social equity, health protection, and human rights.

Financial sustainability represents the need to ensure economic or financial success to the firm and its stakeholders, that it is related to the ability to continuously generate enough cash flow to ensure liquidity and to produce a persistent long-term financial return for the firm and its stakeholders (Longoni, 2014).

Environmental sustainability objectives refer to the consumptions of natural resources at a rate below the natural regeneration or consumptions of alternate resources, generating limited emissions and not being engaged in activities that can degrade the ecosystem (Longoni \& Cagliano, 2015, p.218).

Where social sustainability objectives refer to actively supporting the preservation and creation of skills and capabilities of future generations, promoting health, and supporting equal and democratic social treatments that allow good quality of life, both 
The role of executional strategic cost management techniques in supporting firms' triple bottom line performance

inside and outside firm's context (Longoni \& Cagliano, 2015, p.218).

Accordingly the researcher defines TBL performance as "the performance that achieves the strategic and interrelated financial, environmental, and social objectives simultaneously". However TBL performance has been regarded as a top priority in modern business conditions, there is no universal standards for the evaluation or measurement of TBL performance (Henao, Sarache, \& Gómez, 2019, p.100).

\section{2- Multidimensional measurement of TBL}

\section{performance}

Environmental and social activities have no specific nature and have many different variables and characteristics so sustainability and TBL performance assessment require a variant set of measures that the monetary measurement alone is not suitable for evaluating social and environmental activities (Varsei, et al., 2014, بدوي، محمد ( 2011).

Accordingly it is better to use the multidimensional entrance to measure TBL performance where each TBL subject is evaluated using performance indicator/s suitable for that subject.

Accordingly the researcher had determined 49 TBL performance indicators that are commonly identified by sustainability reporting

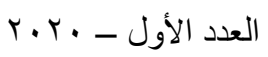$$
\text { Tr }
$$$$
\text { مجلة المحاسبة و المراجعة لإتحاد الجامعات العربية }
$$ 
The role of executional strategic cost management techniques in supporting firms' triple bottom line performance

frameworks and previous sustainability researches and constructed a survey directed to firms listed in the Egyptian index for environmental responsibility, social responsibility, and governance "EGX 100" and asked firms' financial managers, cost managers, responsible in supply chain management (SCM), or sustainability managers about the most calculated and reported TBL performance indicators.

The researcher distributed 15 survey and collected 12 completely answered survey with a response rate of $80 \%$ as follows;

\begin{tabular}{|l|c|c|}
\hline \multicolumn{1}{|c|}{ Business fields } & Frequency & Percentage \\
\hline Basic resources and building & 3 & $16.67 \%$ \\
\hline $\begin{array}{l}\text { Construction and } \\
\text { materials }\end{array}$ & 3 & $25 \%$ \\
\hline $\begin{array}{l}\text { Health services and } \\
\text { pharmaceuticals }\end{array}$ & 2 & $16.67 \%$ \\
\hline Telecommunications & 2 & $16.67 \%$ \\
\hline Food industries & 12 & $100 \%$ \\
\hline Totals & & \\
\hline
\end{tabular}

The results of the survey showed the most calculated and reported TBL performance indicators are as follows;

\begin{tabular}{|ll|l|l|}
\hline \multicolumn{2}{|c|}{ Financial performance indicators } & $\begin{array}{l}\text { No. } \\
\text { of } \\
\text { firm } \\
\text { S }\end{array}$ & $\begin{array}{l}\text { Percent } \\
\text { age }\end{array}$ \\
\hline 1. & Return on sales (ROS) & 12 & $100 \%$ \\
\hline 2. & Return on equity (ROE) & 12 & $100 \%$ \\
\hline 3. & Return on assets (ROA) & 12 & $100 \%$ \\
\hline 4. & Earnings per share & 12 & $100 \%$ \\
\hline
\end{tabular}

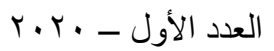


The role of executional strategic cost management techniques

ريهام صفوت in supporting firms' triple bottom line performance

\begin{tabular}{|l|l|l|}
\hline 5. Customer attraction indicator & 11 & $91.7 \%$ \\
\hline $\begin{array}{l}\text { 6. Savings in materials from recycling } \\
\text { activities }\end{array}$ & 10 & $83.3 \%$ \\
\hline $\begin{array}{l}\text { 7. Ratios of standard entry level wage by } \\
\text { gender compared to local minimum wage }\end{array}$ & 9 & $75 \%$ \\
\hline 8. Customers' dissatisfaction indicator & 8 & $66.7 \%$ \\
\hline
\end{tabular}

\begin{tabular}{|l|l|l|}
\hline Environmental performance indicators & $\begin{array}{l}\text { No. } \\
\text { of } \\
\text { firm } \\
\text { s }\end{array}$ & $\begin{array}{l}\text { Percent } \\
\text { age }\end{array}$ \\
\hline $\begin{array}{l}\text { Costs of improving the surrounding } \\
\text { environment d regulations }\end{array}$ & 12 & $100 \%$ \\
\hline $\begin{array}{l}\text { Compliance with environmental laws } \\
\text { and regulations }\end{array}$ & 11 & $91.7 \%$ \\
\hline $\begin{array}{l}\text { 3. Returns from environmentally } \\
\text { friendly products }\end{array}$ & 10 & $83.3 \%$ \\
\hline $4 . \quad$ Materials used by weight or volume & 9 & $75 \%$ \\
\hline $\begin{array}{l}5 . \text { Ratio of recycled input materials } \\
\text { used }\end{array}$ & 8 & $66.7 \%$ \\
\hline $\begin{array}{l}6 . \quad \text { Energy consumption within the firm } \\
\text { from non-renewable sources and types of } \\
\text { these resources }\end{array}$ & 8 & $66.7 \%$ \\
\hline $\begin{array}{l}\text { Ratio of reduction in energy } \\
\text { consumption }\end{array}$ & 7 & $58.3 \%$ \\
\hline $\begin{array}{l}8 . \quad \text { Greenhouse gas "GHG" emissions } \\
\text { and other harmful emissions }\end{array}$ & 5 & $41.6 \%$ \\
\hline
\end{tabular}

r.r. - العدد الأول r. 
The role of executional strategic cost management techniques

ريهام صفوت

in supporting firms' triple bottom line performance

\begin{tabular}{|l|l|l|}
\hline Social performance indicators & $\begin{array}{l}\text { No. } \\
\text { of } \\
\text { firm } \\
\text { s }\end{array}$ & $\begin{array}{l}\text { Percent } \\
\text { age }\end{array}$ \\
\hline $1 . \quad$ Indicator of employees training & 12 & $100 \%$ \\
\hline $\begin{array}{l}\text { 2. Indicator of social contributions for the } \\
\text { country }\end{array}$ & 12 & $100 \%$ \\
\hline $\begin{array}{l}\text { 3. Ratio of employing special needs } \\
\text { individuals (individuals with disabilities) }\end{array}$ & 11 & $91.7 \%$ \\
\hline 4. Indicator of employees training' costs & 10 & $83.3 \%$ \\
\hline $\begin{array}{l}\text { 5. Security and safety considerations' } \\
\text { indicator }\end{array}$ & 9 & $75 \%$ \\
\hline $6 . \quad$ Employees services' costs indicator & 9 & $75 \%$ \\
\hline $7 . \quad$ Customers' dissatisfaction indicator & 7 & $58.3 \%$ \\
\hline $8 . \quad$ Work-related injuries yearly rate & 6 & $50 \%$ \\
\hline
\end{tabular}

\section{$\underline{\text { 3- Executional strategic cost management }}$}

Anderson \& Dekker 2009 defined strategic cost management as "the deliberate alignment of a firm's resources and associated cost structure with long-term strategy and short-term tactics" (Anderson \& Dekker, 2009a, p.201).

And according to El Kelety 2006 strategic cost management is about understanding costs and the causes of costs as well as how to drive the greatest possible productivity through the firm (El Kelety, 2006, p. 77).

Strategic cost management as a system aims to provide firm's management with information for long term cost management and utilization of firm's resources in the light of firm's strategy to

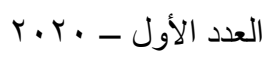


The role of executional strategic cost management techniques in supporting firms' triple bottom line performance

support firm's competitive position. Strategic cost management system consists of two basic subsystems that are;

1- Structural cost management

2- Executional cost management

Both structural and executional cost management help in the utilization of firms' resources and support their competitiveness that they work together to achieve the purpose of strategic cost management.

Executional cost management is a subsystem of strategic cost management that aims to measure the efficiency and effectiveness of executing firm's cost strategy to provide management with information about the success of firm's cost strategy and its implementation.

Executional cost management refers to the cost management activities aimed at improving performance for a given strategy. It is based on common management accounting tools used to measure cost performance in relation with competitive benchmarking to identify improvement opportunities, it basically refers to the analysis of performance after the strategic decisions (Henri, Boiral \& Roy, 2016, p. 270). Executional cost management involves measurement and analysis tools including cost driver analysis and supplier scorecards to evaluate firms' performance and sustainability (Anderson \& Dekker, 2009b, p. 289). 


\section{4-The role of executional strategic cost management} techniques in supporting firms' TBL performance

The research would study the role of the following executional cost management in supporting firms' TBL performance

\section{Activity based costing (ABC)}

ABC appeared at the end of 1960s and the beginning of 1970s where the relationship between cost and activity was analyzed in the context of standard costing and was called activity costing (El Kelety, 2006, p.334), and ABC spread in the writings of Cooper and Kaplan in 1980s, ABC was considered as a method for solving indirect costs' allocation problem of the traditional costing method.

Then $\mathrm{ABC}$ was shifted toward activity and process improvement and led to the emergence of Activity Based Management (ABM) in 1990 's. ABM transferred $\mathrm{ABC}$ from a cost accounting technique to a management perspective, $\mathrm{ABM}$ supports $\mathrm{ABC}$ by using information provided by $\mathrm{ABC}$ 's activity analysis to identify inefficient and non-value added activities (El Kelety, 2006, p. 347). $\mathrm{ABM}$ "emphasizes activity analysis (AA) that consist in understanding the organization's goals and how the processes within the organization work together to accomplish those goals" (Gosselin, 2006, p.645).

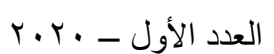

71

مجلة المحاسبة و المراجعة لإتحاد الجامعات العربية 
The role of executional strategic cost management techniques

ريهام صفوت in supporting firms' triple bottom line performance

Consequently $\mathrm{ABC}$ along with $\mathrm{ABM}$ can be used to identify and improve value creating activities and remove waste from operating activities to increase the efficiency and effectiveness of value creating activities across the whole SC.

$\mathrm{ABC} / \mathrm{ABM}$ provide cost information as well as nonfinancial information that help to improve activities efficiency, eliminating non value added activities, and guide process improvement which supports firm's overall performance, and also provide information supporting other techniques including continuous process improvement, value engineering, and TQM (Gosselin, M., 2006, p.645).

$\mathrm{ABC}$ can also be termed as value analysis entrance or perspective and it is one of the main entrances of environmental and social management accounting systems, Although the emergence of the $\mathrm{ABC}$ was not to allocate or to account for the environmental and social costs but it can be used to reduce the possible negative environmental and social effects (إقبال خاطر ، 2011, p.279).

ABC helps firms' management to discover and exploit opportunities of environmental or social advantages when they adopt the philosophy of activity - based environmental and social cost management. where consideration must be given to each activity as a potential source of environmental excellence or

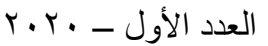
79 مجلة المحاسبة و المراجعة لإتحاد الجامعات العربية 
The role of executional strategic cost management techniques in supporting firms' triple bottom line performance

advantage, by studying the relationship between activity analysis and the basis of classifying activities can be invested is the development of comprehensive classification or integrated classifications to differentiate between the core environmental activities from the environmental sensitive activities, which are economic or social activities which would have important environmental effects خاطر، إقبال, القاضي, محمد بهاء الدين 2002 p. $279,280)$.

\section{$\underline{\text { Life cycle sustainability assessment (LCSA) }}$}

Life cycle cost analysis is one of the important cost management tools that measure the costs during the different stages of the product life for the purpose of controlling them and which include:

- Pre-Manufacturing Costs: including research and development and design costs,

- Manufacturing Costs,

- Post-Manufacturing Costs: including after-sale service, and spare parts and insurance.

Strategic cost management systems without LCC focus basically on costs during the manufacturing phase that LCC support cost drivers identification and performance optimization (Knauer, Möslang, 2018).

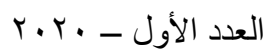$$
\text { مجلة المحاسبة و المراجعة لإتحاد الجامعات العربية }
$$ 
The role of executional strategic cost management techniques ريهام صفوت in supporting firms' triple bottom line performance

Firms' corporate social and environmental responsibility resulted in the emergence of the concepts of full cost from an environmental perspective and sustainable life cycle costing (SLCC) to control the financial, environmental, and social costs during the life of the product or service. SLCC analysis is considered one of the important control tools used in evaluating the environmental and social programs to reflect the continuous improvement objectives, which represent a response to the environmental and social issues such as designing and re-designing for the possibilities of disposing waste, recycling, reusing, or the achievement of various social programs.

In 2011, the United Nations Environment Programme (UNEP) and the Society for Environmental Toxicology and Chemistry (SETAC) have launched the Life cycle sustainability assessment (LCSA) framework and developed a holistic and integrated framework that supports sustainable development and sustainability decision making (Gbededo \& Garza-Reyes, 2018, p.1003).

The UNEP defined LCSA as "the evaluation of all environmental, social and economic negative impacts and benefits in decisionmaking processes towards more sustainable products throughout their life cycle" (UNEP 2011, p.3). 
The role of executional strategic cost management techniques

Product LCSA is the process of evaluating TBL indicators in the whole product life cycle, LCSA provides a holistic evaluation of product's life cycle on the environment and society, LCSA consists of (Environmental Life Cycle Assessment) E- LCA or LCA, LCC (Life Cycle Costing) and S-LCA (Social Life Cycle Assessment) (UNEP 2011, p.1).

\section{$\mathrm{LCSA}=\mathrm{LCC}+\mathrm{LCA}+\mathrm{S}-\mathrm{LCA}$}

LCC calculates and manages the cost of product's life cycle activities, while LCA or (E- LCA) evaluates the environmental impact of resources extraction, transportation, use, production, recycling, and products disposal that LCA is a technique that quantitatively analyze the environmental impact through products' entire life cycle from raw material to disposal, where a full LCA is often "Cradle to Grave" sustainability assessment. And S-LCA assesses product's social effect in all its life cycle stages. LCSA takes into account resources, energy, and waste flow.

From the UNEP LCSA framework, the researcher can conclude that LCSA supports TBL performance at firms' level by the following (UNEP 2011, p.3);

1- Organizes complex TBL data in a structured form.

2- Provides firms with information about the whole life cycle effect of different sustainability alternatives and the positive and 
The role of executional strategic cost management techniques

negative effects of different TBL activities that supports more informed decision making process at different levels.

3- Allows firms to be aware of the full impact of their products and service and be responsible for their business activities which in return supports firms' brand image.

4- Provides awareness about different value chain drivers related to TBL activities.

5- Identify weakness in their current products' life cycles allowing for their improvements and the design of more sustainable products and services

6- Supports innovations that minimizes the negative social and environmental impacts and maximizes the positive impacts.

\section{Sustainability balanced scorecard (SBSC)}

BSC is one of the modern strategic cost management tools interested in measuring institutions' performance to increase their competitiveness in the modern business environment, BSC aims at "balancing financial and non-financial short term and long term as well as qualitative and quantitative success measures" (Kaplan, \& Norton 1996, p.54).

The BSC is used to translate institutions' vision and strategies to objectives and measures based on the four key perspectives which are; financial performance, customer satisfaction, internal business processes efficiency, and opportunities for learning and growth

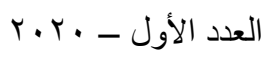

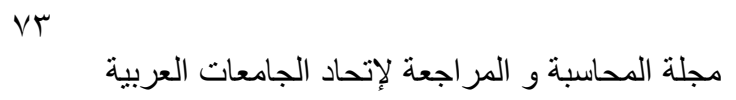


The role of executional strategic cost management techniques in supporting firms' triple bottom line performance

which ultimately lead to achieving financial objectives by cause and effect relationships.

The BSC has been developed as result of firms' social and environmental responsibility and included additional perspective that is the sustainability perspective, where environmental and social issues are integrated in the form of environmental and social strategic and operational objectives with the other four dimensions producing the SBSC.

According to Abdelrazek (2019) SBSC is a performance management system that takes into account sustainability aspect (Abdelrazek, Ahmed Fathi 2019), Hansen \& Schaltegger (2016) view SBSC as "a generic strategic performance management and measurement tool used at various organization levels within organizations with an architecture explicitly incorporating sustainability related strategic objectives visualized with strategy map" (Hansen \& Schaltegger 2016, p.196-197).

SBSC can support firms' TBL performance as follows;

1. SBSC is characterized by its ability to integrate the three dimensions of TBL performance in one performance management system instead of three performance management systems for each dimension. 
The role of executional strategic cost management techniques

ريهام صفوت in supporting firms' triple bottom line performance

2. SBSC is featured by its ability to determine the relationship between long term environmental and social objectives and short term financial goals.

3. SBSC allows for a gradient process of integrating sustainable or TBL strategy in firms' activities through its different perspectives.

\section{5- Research conclusions}

From the previous discussion the researcher concludes that;

1- TBL performance is

- $\quad$ Relatively new concept

- Multidimensional concept

- Requires a strategic long term philosophy

- Considered as a source of creating competitive advantages

- Requires firms' structural and executional changes

- Cannot be measured directly

- Its measurement is based on a set of indicators (multidimensional financial and non-financial indicators).

2- $\mathrm{ABC} \& \mathrm{ABM}$ systems provide firm's management with cost information as well as nonfinancial information that help in improving activities efficiency, eliminating non value added activities, and guide process improvement which supports firm's overall performance, and provide more accurate information about the cost of social and environmental activities allowing for more

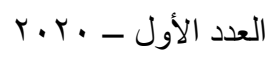$$
\text { vo }
$$

$$
\text { مجلة المحاسبة و المر اجعة لإتحاد الجامعات العربية }
$$


The role of executional strategic cost management techniques in supporting firms' triple bottom line performance accurate cost allocation and more informative decisions, Also Activity - based environmental and social cost management helps firm's management to discover and exploit opportunities of environmental or social advantages through activity analysis that would supports firms' TBL performance.

3- LCSA supports firm's TBL performance by providing information about the whole life cycle effect of different sustainability alternatives and the positive and negative effects of different TBL activities that supports more informed decision making process at different levels and allowing firm's management to be aware of the full impact of their business and be responsible for their activities which in return supports firms' TBL performance.

4- Traditional performance measurement systems have a common weakness which is over-emphasizing on financial measures of performance ignoring other non-financial performance measures which is not suitable for the nature of TBL performance. Where SBSC provides a comprehensive measurement system that helps firms in measuring their TBL performance and in achieving their strategic TBL strategies and objectives. 
The role of executional strategic cost management techniques

ريهام صفوت in supporting firms' triple bottom line performance

\section{$\underline{\text { 6-References }}$}

Abdelrazek, Ahmed Fathi (2019) "Sustainability balanced scorecard: a comprehensive tool to measure sustainability performance " International Journal of Social Science and Economic Research, Vol.04, Issue 2.

Anderson, Shannon W. \& Dekker, Henri C. (2009a) "Strategic cost management in supply chains, part 1: structural cost management" Accounting Horizons, Vol. 23, Issue 2, pp. 201-220.

Anderson, Shannon W. \& Dekker, Henri C. (2009b) "Strategic cost management in supply chains, part 2: executional cost management" Accounting Horizons, Vol. 23, Issue 3, pp. 289-305.

El Kelety, I. (2006) "Towards a conceptual framework for strategic cost management: the concept, objectives and instruments" $\mathrm{PhD}$ Dissertation, University of Chemnitz, Germany

Gbededo, Mijoh A., Liyanage, Kapila \& Garza-Reyes, Jose Arturo (2018) "Towards a Life Cycle Sustainability Analysis: A systematic review of approaches to sustainable manufacturing" Journal of Cleaner Production, Vol. 184, pp. 1002-1015

Gosselin, Maurice (2006) "A Review of Activity-Based Costing: Technique, Implementation, and Consequences" Handbooks of Management Accounting Research, Vol. 2, pp. 641-671

Hansen, Erik G., \& Schaltegger, Stefan (2016) "The Sustainability Balanced Scorecard: A Systematic Review of Architectures",Journal of Business Ethics, Vol.133, Issue 2, pp.193-221

Henao, R., Sarache, W., and Gómez, I. (2019) "Lean manufacturing and sustainable performance: Trends and 
The role of executional strategic cost management techniques in supporting firms' triple bottom line performance

future challenges" Journal of Cleaner Production, Vol. 208, pp. 99116

Henri, Jean-François, Boiral, Olivier, and Roy, Marie-Josée (2016) "Strategic cost management and performance: The case of environmental costs" The British Accounting Review, Vol. 48, Issue2, pp. 269-282

Kaplan, Robert S., \& Norton David P., (1996), "Linking the Balanced Scorecard to Strategy" California management review, vol.39, Issue 1, pp.53-79

Knauer, T. Möslang, K., (2018) "The adoption and benefits of life cycle costing" Journal of Accounting \& Organizational Change, Vol.14, Issue 2, pp.188-215

Longoni, Annachiara (2014) "Sustainable Operations Strategies: The Impact of Human Resource Management and Organisational Practices on the Triple Bottom Line", Springer Cham Heidelberg, available at www.springer.com, ISSN 2282-2585

Longoni, Annachiara \& Cagliano, Raffaella (2015)," Environmental and social sustainability priorities: Their integration in operations strategies ", International Journal of Operations \& Production Management, Vol. 35, Issue 2, pp. 216 - 245.

Schulz, Steven A., \& Flanigan, Rod L., (2016) "Developing competitive advantage using the triple bottom line: a conceptual framework" Journal of Business \& Industrial Marketing, Vol. 31, Issue 4, pp.449-458

Svensson, Göran, et al., (2018) "Framing the triple bottom line approach: Direct and mediation effects between economic, social and environmental elements" Journal of Cleaner Production, Vol. 197, Part 1, pp. 972-991 
The role of executional strategic cost management techniques

ريهام صفوت in supporting firms' triple bottom line performance

United Nations Environment Programme UNEP (2011) "Towards a life cycle sustainability assessment" UNEP/SETAC Life Cycle Initiative

Varsei, Mohsen, et al., (2014) "Framing sustainability performance of supply chains with multidimensional indicators", Supply Chain Management: An International Journal, Vol. 19, Issue 3, and pp. $242-257$

\section{المراجع باللغة العربية}

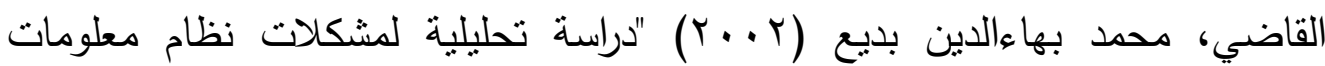

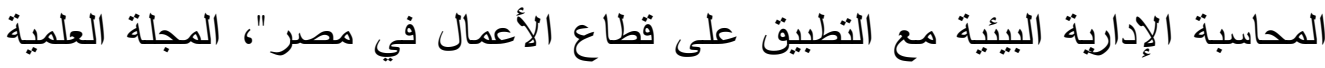
للاقتصاد والتجارة، كلية التجارة، جامعة عين شمس، عددء ، ص545 - 465 ـ

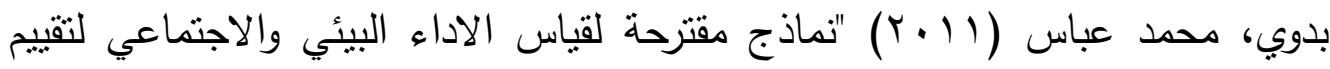

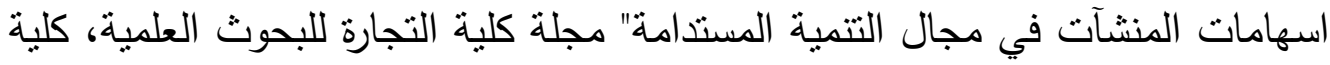

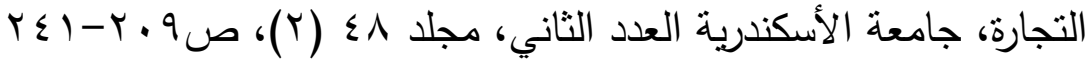

خاطر، إقبال محمد رشاد (2011) " دور نظام المحاسبة الإدارية البيئية في ترشيد قرارات الإدارة لدعم القرة التتافسية لمنظمات الأعمال " مجلة مركز صالح عبداله كامل

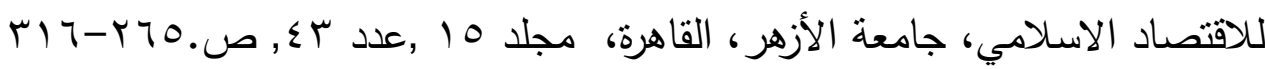

